\title{
Hygiene practices and awareness regarding Milk borne diseases (MBD) among dairy workers in unorganized urban settings of Bhubaneswar, Odisha, India
}

\section{Snigdha Singh ${ }^{1}$, Sonali Kar ${ }^{2}$, Alpana Mishra ${ }^{3}$, Dipti Pattnaik ${ }^{4}$}

${ }^{1}$ Senior Resident, Community Medicine, Kalinga Institute of Medical Sciences, Bhubaneswar, Odisha; ${ }^{2}$ Professor, Community Medicine, Kalinga Institute of Medical Sciences, Bhubaneswar, Odisha; ${ }^{3}$ Assistant Professor, Community Medicine, Kalinga Institute of Medical Sciences, Bhubaneswar, Odisha; ${ }^{4}$ Professor, Microbiology, Kalinga Institute of Medical Sciences, Bhubaneswar, Odisha

\begin{tabular}{|c|c|c|c|c|c|c|c|}
\hline Abstract & Introduction & Methodology & Results & Conclusion & References & Citation & Tables / Figures \\
\hline
\end{tabular}

\section{Corresponding Author}

Dr. Sonali Kar, Kalinga Institute of Medical Sciences, Bhubaneswar, Odisha

E Mail ID: sonsam72@yahoo.co.uk

\section{Citation}

Singh S,Kar S, Mishra A, Pattnaik D. Hygiene practices and awareness regarding Milk borne diseases (MBD) among dairy workers in unorganized urban settings of Bhubaneswar, Odisha, India. J Comm Health. 2021;33(3):466-474. https://doi.org/10.47203/IJCH.2021.v33i03.011

Source of Funding: Nil Conflict of Interest: None declared

Article Cycle

Received: 07/06/2021; Revision: 17/08/2021; Accepted: 05/09/2021; Published: 30/09/2021

This work is licensed under a Creative Commons Attribution 4.0 International License.

\section{Abstract}

Background: Dairy work is thought to be predominantly a rural occupation. However, due to preferences we see a lot of urban residents consume fresh milk and hence, few people even in the urban areas take up cattle rearing as a cost effective profession. In the midst of much talked re-emerging diseases, caused by close habitation of animals and man, it would be very relevant to see living conditions of these populations and their hygiene practices in a space compromised scenario. In urban settings, they stay in close proximity and due to socioeconomic conditions, dairy workers in do not have appropriate amenities to tend on the cattle,clean or even scope for proper waste disposal. This in nutshell, leads to a disease enabling environment and the study aims at reviewing these living conditions. Besides, an assessment of health conditions of the dairy workers, their awareness regarding the milk borne diseases(MBD) was done. The findings helped generate recommendations for improvement of the profession and ultimately the quality of the milk. Objectives:1) Assess the hygiene practices during the stages of milk collection, storage and transport of milk among the sampled dairy workers from urban unorganized settings of Bhubaneswar. 2) Assess awareness of these workers regarding milk borne diseases. Methodology: This cross-sectional survey was part of a larger study and was conducted in unorganized sector of dairy workers in Bhubaneswar. 60 dairy households were surveyed and from each household, 2 members actively involved in dairy work were selected. The study tool was a semi structured, mixed questionnaire. The questionnaire had 3 sections; A was regarding household information(General sociodemographic details and Housing conditions for $60 \mathrm{HHs}$ ); B was to elicit the hygiene status of dairy workers $(n=120)$ during each step of their work, their milk handling details during milk collection, storage and transportation; $\mathrm{C}$ had questions to assess the awareness of dairy worker regarding MBD. Results: Hygiene practices were very dismal at all points like milking,storage and transportation. Only 5.0\% dairy households practised cleaning udder twice- prior to and after milking. Only $35 \%$ households kept the milk storage containers covered. $44.2 \%$ workers agreed that "MBD" is a community health problem. On general examination, pallor and icterus was found among workers. This strongly brings out that this group not only have the potential to be infected by zoonotic diseases, but can also transmit it to through the milk they are selling. A felt need is assessed for these workers in terms of creating standards of hygiene practices of cattle and milk handling and also impart them training on improving their occupational practices.

\section{Keywords}

Dairy household; Dairy worker; Hygiene; Milk borne disease

\section{Introduction}

Dairy farming is an important source of income for 70 million rural households in India that produce an

estimated 139 million tons of milk annually. In states like Odisha, mixed crop and livestock farming is the most predominant farming system for maximum households(1).Dairy workers from the urban 
unorganized sector were defined operationally as "Dairy workers that care for cows that supply milk and oversee the harvesting of their milk, residing in urban slums without being associated to any profession union or dairy organization " (2). As new and often small dairy industries are materializing around the world, an understanding of their needs and challenges is crucial. The knowledge regarding animal husbandry (defined as "production and care of domestic animals"), milk safety, hygiene and environmental responsibility to healthy actions are compromised owing to cultural, geographic and economic constraints of these workers.

Milk is an example of ideal culture medium and acts as ready made vehicle for harboring,favouring and enhancing foodborne pathogens, namely $S$. aureus(3,4,6),Strept. Species(7), E.coli(4,8), Bacillus(7), in milk causing serious health risk on consumption, broadly termed as "Milk-borne diseases"(9).

Negligence of the poorly oriented dairy workers towards this public health problem holds a major concern. This study was conceived to assess dairy workers in urban areas, who are usually migrants from rural areas, for their hygiene practices and proneness to infections arising thereof. The study would also in a subtle way hint at safety of the milk sold by these workers.

\section{Aims \& Objectives}

1. To explore the demographic, social, environmental conditions of dairy workers.

2. To assess the gaps in hygiene practices during the stages of milk collection, storage and transport of milk

3. To assess awareness regarding milk borne diseases in the dairy worker

\section{Material \& Methods}

The study was undertaken with an aim of qualitatively assessing the hygiene practices and awareness regarding milk borne diseases of workers in the small scale dairy households, with a focus on cattle health management practices from September 2018 to January 2020. The results discussed are part of a larger study, which was a thesis dissertation. After due clearance from IEC in 2018 (Ref.No.KIMS/KIIT/IEC/088/2018), the study was initiated in Bhubaneswar. It had no source of funding and any conflict of interest.

Sampling: A community- based, descriptive crosssectional survey was planned. The sample size was calculated with a presumption of $50 \%$ dairy workers maintaining hygiene practices and $50 \%$ of these workers are aware regarding milk borne diseases, at 95\% desired confidence level with $20 \%$ of relative precision. Our required sample size for the current study was 100. Presuming a non-response of $10 \%$, optimum target sample size taken was 110 . But the data was collected for a larger sample of 120 small scale dairy workers from 60 dairy households, in the urban settings of Bhubaneswar after considering the inclusion criteria. It was a challenge to achieve the requisite sample size since these workers reside scattered in slums/ semi slum areas of the city and being unorganized, there is no listing of these households. This was also the rationale behind taking 2 workers from one household, so as to get the requisite sample size.

Inclusion criteria- Resident of Bhubaneswar ( $>5$ years), age $\geq 18$ years, irrespective of the gender, engaged in this profession for at least one year and working actively in the dairy for at least 2-4 hours /day and those who consented to participate.Multistage random sampling was used to identify wards and thereon dairy households with the dairy respondents were obtained by a house to house search in each Zone of Bhubaneswar(Figure 1).

Interview and general physical examination: The participants were interviewed using the semi structured, mixed(both open and close ended) questionnaire during a house visit, by a team led by the researcher, interns and health worker. The tool was self-developed using references from similar articles from literature $(10,11,12,13)$ and tested for internal and external validity.Expert veterinary doctors were consulted for hygiene practices in these workers and their inputs were incorporated.The tool was translated and back translated into local language Odia, for the ease of eliciting answers by researcher.The questionnaire was pilot tested in 15 households before being finalized for the study. The cattle rearing set up, practices of milking, storage and cattle rearing were observed for the requisite findings. The information included in study are observations of the researcher.

Hand hygiene practice was considered ideal if hands were washed before and after milking and prior to milk distribution, using soap and water for 40-60 seconds as recommended by WHO while udder hygiene practices were considered good when cleaned before and after milking, dried using towel separate for each cattle, teat sealed during mastitis or antibiotic therapy. As there are no standards of hygiene practices and no regulatory body to monitor their work, this was a profession which was built on age old practices.

The respondents were also subjected to general health check up and quizzed for relevant past histories.

Statistical analysis: Data was organized and coded in Microsoft excel sheet. Qualitative data were analyzed thematically while quantitative data were analysed using descriptive statistics. SPSS-23 was used for analysis. $X 2$ test and Fischer exact test were applied as appropriate and $p$-value of $<0.05$ was considered to be significant.

\section{Results}

Demographic characteristics : (Table1) indicates that more respondents(55.9\%) were female (as the work requires less movement), majority (40\%) were in the age group of 31-40 years and all participants were Hindus which could be because of their religious culture, who 
have always considered cattle for their milk and never for meat, moreover considering the dairy work as holy affair. For the given sample, majority were illiterate hinting that this was a profession of the less read. Small scale dairy farms in Bhubaneswar commune are unorganized and mostly family-run. Select sample reported a mean of 18.15 years of dairy farming experience, with a minimum of 4 years and maximum of 43 years of experience. $31.7 \%$ workers had less than or equal to 17 years of experience in dairy farming while majority (68.3\%) had a greater experience. $40 \%$ dairy households had migrated to Bhubaneswar from rural Odisha before 5 years or more, with respect to the date of survey. Bhubaneswar, where the study was done, is developing at a good pace since a few years and has become a commercial hub attracting people from their native places to earn a better livelihood. Thus, a span of minimum 5 years stay in Bhubaneswar was considered to assess their migration status.

$86.6 \%$ workers named dairy work as their only source of income while $13.4 \%$ workers were involved in other occupation also like working as vendors, maid, shopkeeper, driver, etc. The monthly income was found to be Rs. 30,000-5,55,000.

Housing and living condition of dairy workers: (Figure 2) depicts the housing and living condition of dairy workers. $41.6 \%$ dairy households reported to be discarding the waste produced in house once daily. This was important in this study as lack of prompt disposal of waste especially of the diary animals added to the disease enabling environment in the household. In 95\% houses, there was evidence of mosquitoes.On enquiring about the source of drinking water, $61.7 \%$ households had tap supply. This proves that inspite of having a good income from the profession, the standard of living for these families were very compromised.

Our literature review does not give evidence of any study reporting findings on living conditions of the small scale dairy workers.

Cattle sheds in the small scale dairy farms : (Figure 3) describes cattle sheds surveyed in the study. Most (86.6\%) reported cleaning the cattle shed once/day, although $13.4 \%$ households reported cleaning more than 3 times per day. Interestingly,workers with less experience( $\leq 17$ years into dairy occupation) seemed on average, to clean cattle sheds more frequently. $31.7 \%$ households reported using combination of water and any of the antiseptic solution like phenyl, carbolic acid or dettol.It was observed in $51.7 \%$ sheds that there was co inhabitation by other pets like dogs, cats and poultry besides dairy cattle in the premises. This was identified as potential cause promoting zoonotic diseases.

Hygiene practice of dairy workers during milk collection : Milking practices of small scale dairy commune were largely dependent on manual labor and family cooperation, as no automated machinery was used. All the dairy households reported milking by hand using the knuckling technique. The low practice(25.9\%)of not washing hands prior to milking (Table 2) was attributed to the fact that since milking was usually an early morning activity, undertaken after the morning toilet use or after afternoon nap, the participants speculated that their hands were clean.Also these households lacked uninterrupted water supply. It was found that only $38.3 \%$ dairy households cleaned cattle udder using warm/boiled water while rest used normal water. After udder cleaning, $23.4 \%$ households were found to be using towels to wipe the udder which was common for all the cattle and the towel was washed on alternate days by $50 \%$ households.

Hygiene practice of dairy workers during milk storage: (Table 3 ) shows the hygienic practices of small scale dairy household during milk storage. It was observed that none of the dairy households used filters while pouring milk from collection buckets to storage buckets while none of the small scale dairy households had milk tanks for storage. On observing if water was added to milk during storage, $26.6 \%$ dairy households did so, of which only $25 \%$ conducted procedures (mostly boiling) to make water safe to be added to milk.

Hygiene practice of dairy workers during milk transport and distribution: (Table 4) depicts good hygiene practices during milk transport and distribution. The present study reports that the practice of adulterating milk with water was carried out mostly twice - immediately after milking and prior to distribution. Judgement on the total amount and ratio of water being added to the milk could not be made since it could be considered by the participants as breach in their professional privacy.

Commercially sold milk undergoes pasteurization, while a notable amount of raw milk is consumed locally due to several traditional beliefs. It was found that $75.5 \%$ (37/49) of the dairy households that consume their own milk consume unpasteurized milk, which could pose a health risk to these consumers. On enquiring about the reason for consumption of raw milk by household members, majority (36/98) of the respondents reported that raw milk was healthy and boiling it would reduce its nutritive value.

Awareness of dairy workers on milk borne diseases: (Table 5) represents awareness of dairy workers on milk borne diseases. Every participant understood "milk contamination". On assessment of the workers knowledge on ways of contamination of milk, not covering milk stored with lid and unclean storage containers were responses of majority while $40.8 \%$ considered ingestion of raw milk to be mode of transmission of milk borne diseases. Figure 4 shows the awareness vs. practice among dairy workers on certain hygiene and disease prevention (self and cattle) measures.

Among the dairy workers with less years of experience ( $\leq 20$ years), $74.4 \%$ were conscious regarding their hands being one of the routes for milk contamination. This was found statistically significant $(p=0.018)$ which can be 
attributed to the fact that they were more receptive and technologically sound i.e.having better access to information on hygiene over television or social media. The gaps in awareness and practices (Figure 4) reinforce that awareness alone doesn't pave way to changing practice, but regulations, monitoring and reinforcement for quality driven services alone can ensure good practices.

\section{Discussion}

Socio demographic characteristics - Majority of the dairy workers were aged more than 31 years in previous studies $(13,14,15,16,17,18)$, in line to finding of current study. Ngasala et al. (2015) (19) in a study in Tanzania and Neeta et al. (2014)(11), studying dairy workers of Belgaum (Karnataka, India) reported more females, 94\% participants had received primary education and $55.2 \%$ workers were illiterate, respectively and later study reported $72 \%$ Hindus as against $100 \%$ in ours.Contrarily studies from Pondicherry (14) and Southwest Ethiopia (17) report workers to be predominantly male. The study in Chandigarh shows 39\% participants were qualified up to secondary level (16)

A previous study from Chandigarh reports that the monthly income from dairy ranged from Rs. 30,000$1,20,000$ and their mean years into the occupation was reported to be $19.09 \pm 12.32$ years (12). This was in contrary to our study where we found monthly income of Rs. 30,000-5,55,000 and years into occupation to be from 4-43 years. This may be explained by the regional preferences among the region specific population for fresh milk, who are ready to purchase it at higher costs. The higher earning may also explain the reason why this sample has dedicated more years into the profession as compared to reports from other studies (14) which reported years into occupation of dairy workers in Pondicherry to be 12-30 years, similar to our finding.

Cattle sheds in the small scale dairy farms: In contrary to the present findings, a study done in Rajasthan (20) reveals that only $38.75 \%$ dairy households kept their cattle in separate sheds whereas the study in Belgaum shows only $8.2 \%$ had separate cattle sheds(11). This variation from current study can be attributed to the general custom of people in Bhubaneswar to keep their animals in separate confinement,although not very far from their dwelling area,to fulfil the safety and cleanliness purpose within the land they have.

Current study shows $71.7 \%$ sheds inadequately ventilated, making it congested due to poor ventilation and cattle overcrowding. Improper ventilation could lead to respiratory diseases in human like $\operatorname{LTBI}(21)$ or breathing difficulty $(22,23)$ due to accumulation of gas produced by cattle(24), skin infections $(24,25)$ and on the other hand spread infection from an infected cattle to the rest $(16,26)$. Similar to ours, a study in Rajasthan shows all the cattle sheds having kutcha floor, brick with cement walls
(51.7\%), thatched roof (70.5\%),few sheds(12\%) having gutter for drainage(20) and only $18.25 \%$ having proper light facility due to lack of electricity in many rural areas of Rajasthan. An ideal shed should have concrete flooring as it stands cheap and durable and in the tropical climate, provides the required cool condition for animals.Moreover, rough surface prevents accidents like slipping. Finding of this study on cleaning shed daily is also in accordance to ours.

Hygiene practice during milk collection: Some previous studies $(10,11,12,13,27)$ reported partial adoption of hand washing practice prior to milking in accordance to our finding. A study showed that washing hands prior to milking was better in upper SES class than in lower class in dairy workers of Belgaum (11) while another study in China(27) reported only $24 \%$ workers to be washing hands appropriately. This is in contrary to other studies which reported majority of the dairy workers washed hands prior to milking $(20,26,28,29)$.For an effective hand washing, use of soap/ antiseptics stands essential. Finding of current study is nearly in agreement with that observed in Beijing, 24\% showed appropriate way to wash hands, which included wetting,applying soap, rubbing for 20 seconds, rinsing and drying hands (27).

Dairy workers cleaning cattle udder as pre milking treatment in our study is in contrary to the findings of study in Belgaum (11) and Ethiopia (22) where $5.00 \%$ and 82.6\% workers reported not cleaning the udder, respectively. However, many studies reported a better udder cleaning practice by $100 \%(14,20,29), 99.2 \%$ (30) and $87.0 \%$ (26). Use of separate towels to wipe and dry the cleaned udder is an appreciated practice to prevent udder infection and milk contamination(31).Of the dairy workers who practised udder washing followed by its drying, using common towel to dry udder was reported in our study $(23.4 \%)$ but in contrary to Surkar et al. (2014)(89.1\%)(13).

Post milking teat dipping into antiseptic/ warm water prevents udder exposure to flies, insects and microbial flora. This precaution was not taken in any of the dairy farms during our study which is similar to many prior studies(13,14,32).28.4\% farms in present study performed udder cleaning only before milking while $66.6 \%$ cleaned it after milking only. Belay and Geert (2015) reported $96.3 \%$ dairy farmers practising udder wash prior to milking (12) while another study reports that $50 \%$ respondents practised regular udder washing before milking in Karnataka (11) and 62\% washed udder only after milking in Kerala (32).

Hygiene practice during milk storage: In the present study, none of the small scale dairy households had milk tanks for storage unlike finding of a study which reports $67 \%$ having milk tanks (33). The milk was being stored in buckets in all the dairy households taken up in our study, similar to other studies $(11,13,29,34)$. We found only $28.3 \%$ households cleaning the milk storing containers 
which is similar to finding reported by study in Belgaum(11)while study in Wardha(13) shows majority (79.1\%) kept storage containers clean.

Milk contains a natural inhibitory system or temporary germicidal or bacteriostatic properties which prevents a significant rise in the bacteria count during the first $2-3$ hours $(35,36)$ if cooled to temperature of 4 으 within this period immediately after milking that helps maintain its quality and safety for consumption $(9,36)$.

Our study found all the dairy farms to be storing milk at room temperature which is similar to finding of the studies done by Majalija et al.(2020) (37) and Neeta et al.(2014) (11). Water was found to be the most common adulterant added to milk in our study, similar to study in Kenya (37) and Belgaum (11) while the study in Chandigarh(16)showed $85.4 \%$ not practising milk adulteration.

Hygiene practice during milk transport and distribution: The containers for milk transport were found to be made of plastic, similar to many other studies-75\% (Majalija et al. (2020) (37), 100\% (Ngasala et al.(2015)) (19). The rough surfaces of plastic containers prevent effective cleaning and sanitization and this increases bacterial contamination of milk (37). Use of aluminium or metal containers is encouraged for easy cleaning and durability. Use of masks/ caps to prevent milk contamination was practised by $19.1 \%$ dairy workers in our study in contrast to study in Beijing where $85 \%$ respondents reported wearing work uniform and cap always (27).

Commercially sold milk undergoes pasteurization, while a notable amount of raw milk is consumed locally due to several traditional beliefs. It was found that $75.5 \%$ (37/49) of the dairy households that consume their own milk consume unpasteurized milk, which could pose a health risk to these consumers, according to few similar studies $(11,19)$.

Awareness of dairy workers on MBD: Similar finding on level of awareness regarding MBD were reported by many studies- Malija et al. (2020) (75\%) (37), Neeta et al.(2014) (0\%) (11), Dimphetego et al. (2010) (36.7\%) (38), as majority participants didn't know that milk contamination could cause disease.

The knowledge on modes of transmission of MBD were considered to be ingestion of raw milk (40.8\%) in our study in accordance with previous studies Dimphetego et al. (2010) (38), Belay and Geert (2015) (12) where it was reported to be $63.9 \%, 35 \%$, respectively in a better line to some other studies where none of the dairy workers knew milk to be transmitting disease (11). On assessment of the workers knowledge on ways of contamination of milk, not covering milk stored with lid and unclean storage containers were responses of majority $(11,19)$. Finding of our study was encouraging than that reported in Ethiopia in 2017 where only $13 \%$ dairy workers had knowledge regarding raw milk consumption causing diseases (22).

\section{Conclusion}

This is a simple study with the pertinent objectives to highlight the dairy practices among the unorganized dairy workers in city.It has brought out glaring callousness among all hygiene practices, which are camouflaged by less education and unhindered demand of milk even in the city.

The city does not have any system or body to monitor work of these workers and offer them help in terms of training and funds to improvise their services. Unlike in the west where this profession is dealt with utmost importance, in our country we are evasive towards introduction of any technology or mechanics into these professions. Surprisingly no use of machines was identified, even in households who were earning very well. Machines and refrigeration can help do away with repeated hand washing and assure safety of the milk, yet none of the workers invested in these modern means.

\section{Recommendation}

It is strongly recommended that small scale professions like these to be integrated into governmental protection in terms of giving them funds and up scaling their services which will be more quality driven and serve to offer them a healthy quality of life too.

\section{Limitation of the study}

The study is rife with limitations as a robust sample could not be covered no listing of the households was done, milk safety and blood parameters of the workers could not be assessed for conclusive results, as it was entirely selffunded. Yet, it has brought out very strongly the vulnerability of these populations to milk borne diseases and also raises doubts on the quality of the milk delivered.

\section{References}

1. Saha A, Garcia O, Hemme T. The Economics of Milk Production in Orissa, India, with particular Emphasis on Small-scale Producers. Food and Agriculture Organization of the United Nations, Pro-Poor Livestock Policy Initiative. 2004;1-4.

2. Douphrate DI, Gimeno D, Nonnenmann MW, Hagevoort R, RosasGoulart C, Rosecrance JC. Prevalence of work-related musculoskeletal symptoms among US large-herd dairy parlor workers. American journal of industrial medicine. 2014;57(3):3709.

3. Mahony FO. International Livestock Centre for Africa Manual No. 4 Rural dairy technology Experiences in Ethiopia.1988. ISBN 92-9053092-8.

4. El-Leboudy AA, Amer AA, Aansary M El. Assessment of Microbial Quality of Rural and Urban Raw milk. Alexandria J Vet Sci. 2016;51(2):310-6.

5. Roberson JR, Fox LK, Hancock DD, Gay JM, Besser TE. Ecology of Staphylococcus aureus Isolated from Various Sites on Dairy Farms. J Dairy Sci [Internet].1994;77(11):3354-64. Available from: http://dx.doi.org/10.3168/jds.S0022-0302(94)77277-5

6. Oliver SP, Jayarao BM, Almeida RA.Foodborne Pathogens in Milk and the Dairy Farm Environment: Food Safety and Public Health Implications. Foodborne Pathog Dis. 2005;2(2):115-29.

7. Dhanashekar R, Akkinepalli S, Nellutla A. Milk-borne infections. an analysis of their potential effect on the milk industry. Germs. 2012;2(3):101-9. 
INDIAN JOURNAL OF COMMUNITY HEALTH / VOL 33 / ISSUE NO 03 / JUL-SEP 2021

8. Zeinhom MMA, Abdel-Latef GK. Public health risk of some milk borne pathogens. Beni-Suef Univ J Basic Appl Sci [Internet]. 2014;3(3):209-15. Available from: http://dx.doi.org/10.1016/j.bjbas.2014.10.006

9. Omore A, Lore T, Staal S, Kutwa J. Addressing the public health and quality concerns towards marketed milk in Kenya. 2005.

10. Kamana O, Jacxsens L, Kimonyo A, Uyttendaele M. A survey on hygienic practices and their impact on the microbiological quality and safety in the Rwandan milk and dairy chain. Int J Dairy Technol. 2017;70(1):52-67.

11. PN N, N P, MS S, MD M. A study on awareness regarding milk borne diseases in an urban community of Karnataka. Int J Med Sci Public Heal. 2014;3(9):1093.

12. Duguma B, Janssens GP. Assessment of dairy farmers' hygienic milking practices and awareness of cattle and milk-borne zoonoses in Jimma, Ethiopia. Assessment. 2015;45.

13. Surkar SH, Sawarkar SW, Kolhe RP, Basunathe VK. Adoption of quality milk production practices by dairy farmers in Wardha District of Maharashtra. Agriculture and Rural Development International. 2014;1(1):1-4.

14. Patel Janki, Kumar D, Jothi NA and Balagopalan TP. A Study of Milker's Callus in Milk Men. World Journal of Veterinary Science. 2020;8:12-14.

15. Abunna F, Tasew N, Ragassa F, Ayana D, Amenu K. Handling Practices, Quality and Safety of Milk along the Dairy Value Chains in Selected Sub Cites of Addis Ababa, Ethiopia. Biomed J Sci \& Tech Res. 2019;13(1): 9652-9665.

16. Ekta D, Singh KD, Ghai S. Effectiveness of an educational package on milk hygiene practices of dairy workers of Milk Colony, Dhanas, Chandigarh, India. International Journal of Scientific Research And Education. 2020;7(12).

17. Gemechu T, Amene T. Dairy cattle milk production, handling, processing, utilization and marketing system in Bench Maji Zone, Southwest Ethiopia. International Journal of Livestock Production. 2017;8(9):158-67.

18. Pant J, Amit L. Assessment of working problems and designing of protective clothing for female dairy workers. International Journal of Academic Research and Development. 2017;2(5): 14-17.

19. Ngasala JU, Nonga HE, Madundo M, Mtambo A. Assessment of raw milk quality and stakeholders' awareness on milk-borne health risks in Arusha City and Meru District, Tanzania. Tropical Animal Health and Production. 2015 Jun 1;47(5):927.

20. Rathore RS, Singh R, Kachwaha RN, Kumar R. Existing management practices followed by the cattle keepers in Churu district of Rajasthan. Indian Journal of Animal Sciences. 2010;80(8):798-805.

21. Torres-Gonzalez P, Soberanis-Ramos O, Martinez-Gamboa A, Chavez-Mazari B, Barrios-Herrera MT, Torres-Rojas M, CruzHervert LP, Garcia-Garcia L, Singh M, Gonzalez-Aguirre A, de LeonGarduño AP. Prevalence of latent and active tuberculosis among dairy farm workers exposed to cattle infected by Mycobacterium bovis. PLoS Negl Trop Dis. 2013;7(4):e2177.

22. Ayele Y, Gutema FD, Edao BM, Girma R, Tufa TB, Beyene TJ, Tadesse F, Geloye M, Beyi AF. Assessment of Staphylococcus aureus along milk value chain and its public health importance in Sebeta, central Oromia, Ethiopia. BMC microbiology. 2017;17(1):141.

23. Eastman C, Mitchell DC, Bennett DH, Tancredi DJ, Mitloehner FM, Schenker MB. Respiratory Symptoms of California's Dairy Workers
[Hygiene practices...] | Singh S et al Chelsea Eastman. Field Actions Science Reports. The journal of field actions. 2010;(Special Issue 2).

24. Harries MJ, Lear JT. Occupational skin infections. Occup Med (Chic III). 2004;54(7):441-9.

25. Maslen MM. Human cases of cattle ringworm due to Trichophyton verrucosum in Victoria, Australia. Australas J Dermatol. 2000;41(2):90-4.

26. Tewari H, Kumar S, Singh DV, Rath R, Tyagi K. Studies on existing milking and health care practices adopted by dairy farmers in Tara region of Uttarakhand, India. Indian Journal of Animal Research. 2018;52(3):454-8.

27. Chen $\mathrm{Y}$, Ji $\mathrm{H}$, Chen LJ, Jiang $\mathrm{R}, \mathrm{Wu}$ YN. Food safety knowledge, attitudes and behavior among dairy plant workers in Beijing, northern China. International journal of environmental research and public health. 2018;15(1):63.

28. Tegegne B, Tesfaye S. Bacteriological milk quality: Possible hygienic factors and the role of staphylococcus aureus in raw bovine milk in and around Gondar, Ethiopia. Int J Food Contam [Internet]. 2017;4(1):1-9. Available from: http://dx.doi.org/10.1186/s40550016-0046-2

29. Kashongwe OB, Bebe BO, Matofari JW, Huelsebusch CG. Associations between milking practices, somatic cell counts and milk postharvest losses in smallholder dairy and pastoral camel herds in Kenya. International Journal of Veterinary Science and Medicine. 2017;5(1):57-64

30. Moxley JE, Kennedy BW, Downey BR, Bowman JS. Survey of milking hygiene practices and their relationships to somatic cell counts and milk production. Journal of Dairy Science. 1978;61(11):1637-44.

31. Pankey JW. Premilking udder hygiene. Journal of dairy science. 1989;72(5):1308-12.

32. Asiya P, Gopi G. Socio-economic Profile and Adoption of Recommended Milking Practices among Small Dairy Farmers of Meenangadi Gram Panchayat of Wayanad District of Kerala. Mapana Journal of Sciences. 2019;18(4):41-51

33. Adjlane-Kaouche $S$, Benhacine R, Ghozlane F, Mati A. Nutritional and hygienic quality of raw milk in the mid-northern region of Algeria: Correlations and risk factors. Sci World J. 2014:1-7.

34. Millogo V, Sissao M, Sidibé AG, Ouédraogo GA. Effect of storage time and temperature on raw milk composition of dairy cattle in tropical conditions. African Journal of Dairy Farming and Milk Production. 2015;2:104-8.

35. Swai E, Schoonman L. Microbial quality and associated health risks of raw milk marketed in the Tanga region of Tanzania. Asian Pac J Trop Biomed. 2011;1(3):217-22.

36. Abera Y, Angaw M. Handling Practice and Microbial Quality of Raw Cow's Milk Produced and Marketed In Adigrat Town, North Eastern Tigray. Journal of Biology, Agriculture and Healthcare. 2015;5:15.

37. Majalija S, Tumwine G, Kiguli J, Bugeza J, Ssemadaali MA, Kazoora HB, Muwanguzi EN, Nantima N, Tuyiragize R. Pastoral community practices, microbial quality and associated health risks of raw milk in the milk value chain of Nakasongola District, Uganda. Pastoralism. 2020;10(1):1-1.

38. Mosalagae D, Pfukenyi DM, Matope G. Milk producers' awareness of milk-borne zoonoses in selected smallholder and commercial dairy farms of Zimbabwe. Tropical animal health and production. 2011;43(3):733-9.

\section{Tables}

TABLE 1 FREQUENCY DISTRIBUTION OF DAIRY HOUSEHOLDS ( $N=60$ )AND WORKERS $(\mathrm{N}=120)$ ACCORDING TO SOCIO - DEMOGRAPHIC CHARACTERISTICS

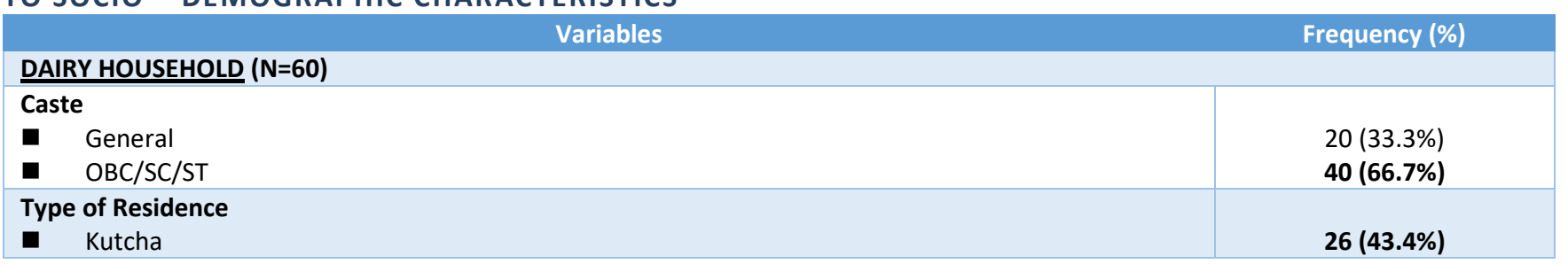


Ownership of house

- Own

- Rented

Family type

- Nuclear

Joint $/ 3^{\text {rd }}$ generation

47 (78.3\%)

No. of family members

- Less than equal to 4

$13(21.7 \%)$

- 5-8

$9(15.3 \%)$

5-8

$43(71.5 \%)$

$8(13.2 \%)$

DAIRY WORKERS ( $\mathrm{N}=120)$

Education status

- Illiterate

- Primary school

- Middle school and above

62 (51.6\%)

$49(40.9 \%)$

Socio Economic status (Modified B.G.Prasad Scale 2020)

- I-Upper class

$9(7.5 \%)$

- II-Upper middle class

114 ( 95\%)

$6(5 \%)$

\section{TABLE 2 HYGIENE PRACTICES WHILE MILK HANDLING AND COLLECTION}

\begin{tabular}{|c|c|}
\hline Variables & Frequency(\%) \\
\hline \multicolumn{2}{|l|}{ AT INDIVIDUAL WORKER LEVEL ( $\mathrm{N}=120)$ : } \\
\hline \multicolumn{2}{|l|}{ Hand washing practised before milking* } \\
\hline - Yes & $31(25.9 \%)$ \\
\hline - No & 89 (74.1\%) \\
\hline \multicolumn{2}{|l|}{ Hand washing done using $(n=31)$} \\
\hline - Soap and water (ideal) & $11(35.5 \%)$ \\
\hline - Only water & $20(64.5 \%)$ \\
\hline Practice of handling milk with bare hands if wounded* & $90(75 \%)$ \\
\hline \multicolumn{2}{|l|}{ AT DAIRY HOUSEHOLD LEVEL $(\mathrm{N}=60)$ : } \\
\hline \multicolumn{2}{|l|}{ Practice of Udder cleaning } \\
\hline - Yes & $47(78.3 \%)$ \\
\hline - Sometimes & $13(21.7 \%)$ \\
\hline \multicolumn{2}{|l|}{ Time of udder cleaning } \\
\hline - Before milking & $17(28.4 \%)$ \\
\hline After milking & $40(66.6 \%)$ \\
\hline - Both before and after milking(ideal) & $3(5 \%)$ \\
\hline \multicolumn{2}{|l|}{ Milk collection bucket made up of - } \\
\hline - Aluminium (ideal) & $17(28.3 \%)$ \\
\hline - Steel & $14(23.4 \%)$ \\
\hline - Plastic & $29(48.3 \%)$ \\
\hline \multicolumn{2}{|l|}{ Practice of washing of milk collection buckets } \\
\hline - Yes & $17(28.3 \%)$ \\
\hline - No & $43(71.7 \%)$ \\
\hline
\end{tabular}

\section{TABLE 3 HYGIENE PRACTICES AT DAIRY HOUSEHOLD LEVEL DURING MILK STORAGE, N=60}

\begin{tabular}{|l|c|}
\hline \multicolumn{1}{|c|}{$\begin{array}{c}\text { Variables } \\
\text { Cleaning of storage containers prior to pouring milk }\end{array}$} & Frequency reporting the practice (\%) \\
\hline \begin{tabular}{|l|} 
Storage container is kept \\
$\mathbf{\square} \quad$ Covered with lid
\end{tabular} & $21(28.3 \%)$ \\
\hline Milk storage area clean and free of insects/flies & $39(65 \%)$ \\
\hline Water is added to milk during storage & $17(28.3 \%)$ \\
\hline Procedure done for making water safe to be added to milk (n=16) & $16(26.6 \%)$ \\
\hline Fate of left out milk & $4(25 \%)$ \\
\hline$\quad$ Added to next day's collection & $21(35 \%)$ \\
\hline$\quad$ Milk products & $39(65 \%)$ \\
\hline The area of milk collection and storage is same & $34(56.6 \%)$ \\
\hline
\end{tabular}


TABLE 4 HYGIENE PRACTICES AT DAIRY HOUSEHOLD AND WORKER LEVEL DURING MILK TRANSPORT AND DISTRIBUTION

Variables $\quad$ Frequency reporting the practice (\%)

\section{AT DAIRY WORKER LEVEL ( $\mathrm{N}=120)$ :}

Hand washing before distributing milk to

consumers $(n=120)$

- Yes

- No

- Sometimes

Cap/mask worn during distribution $(n=120)$

AT DAIRY HOUSEHOLD LEVEL $(\mathrm{N}=60)$ :

The inmates boil the raw milk before intake $(n=49 H \mathrm{H}) *$

- No

- Sometimes

*11 HH were excluded as milk was not consumed by the inmates

Container for transport cleaned before pouring in milk $(n=46)$

- Yes

- No

- Sometimes

Milk drawn out from container using vessel with a handle

Time taken to dispatch milk after storage :

1-4hours

Milk container is properly packed while transportation

Area within which milk is usually transported

- Very close to house

$16(13.4 \%)$

$81(67.5 \%)$

$23(19.1 \%)$

$23(19.1 \%)$

- Different ward

Other zone

$37(75.5 \%)$

$12(24.5 \%)$

15 (32.6\%)

$23(50 \%)$

$8(17.4 \%)$

$35(58.3 \%)$

60 (100\%)

19 (31.7\%)

14 (23.4\%)

22 (36.6\%)

24 (40\%)

\section{TABLE 5 AWARENESS OF DAIRY WORKERS ON MILK BORNE DISEASES, N=120}

\begin{tabular}{|l|c|}
\hline Ways of milk contamination *- & Variables \\
\hline Due to environment & $114(95 \%)$ \\
\hline By hands & $81(67.5 \%)$ \\
\hline Unclean udder & $116(96.6 \%)$ \\
\hline During storage & $93(77.5 \%)$ \\
\hline During transportation & $33(27.5 \%)$ \\
\hline Milk pasteurization prior to consumption prevents milk borne diseases & $49(40.8 \%)$ \\
\hline Awareness on types of milk borne disease *- & $\mathbf{4 2 ( 3 5 \% )}$ \\
\hline Tuberculosis & $29(24.1 \%)$ \\
\hline Anthrax & $1(0.8 \%)$ \\
\hline Brucellosis & $17(14.2 \%)$ \\
\hline Fungal & \\
\hline “Milk borne disease" as a community health problem & $53(44.2 \%)$ \\
\hline Vaccination prevents cattle against diseases & $80(66.6 \%)$ \\
\hline * This question had multiple responses from every dairy worker & \\
\hline
\end{tabular}




\section{Figures}

FIGURE 1 FLOW CHART SHOWING STUDY SAMPLING

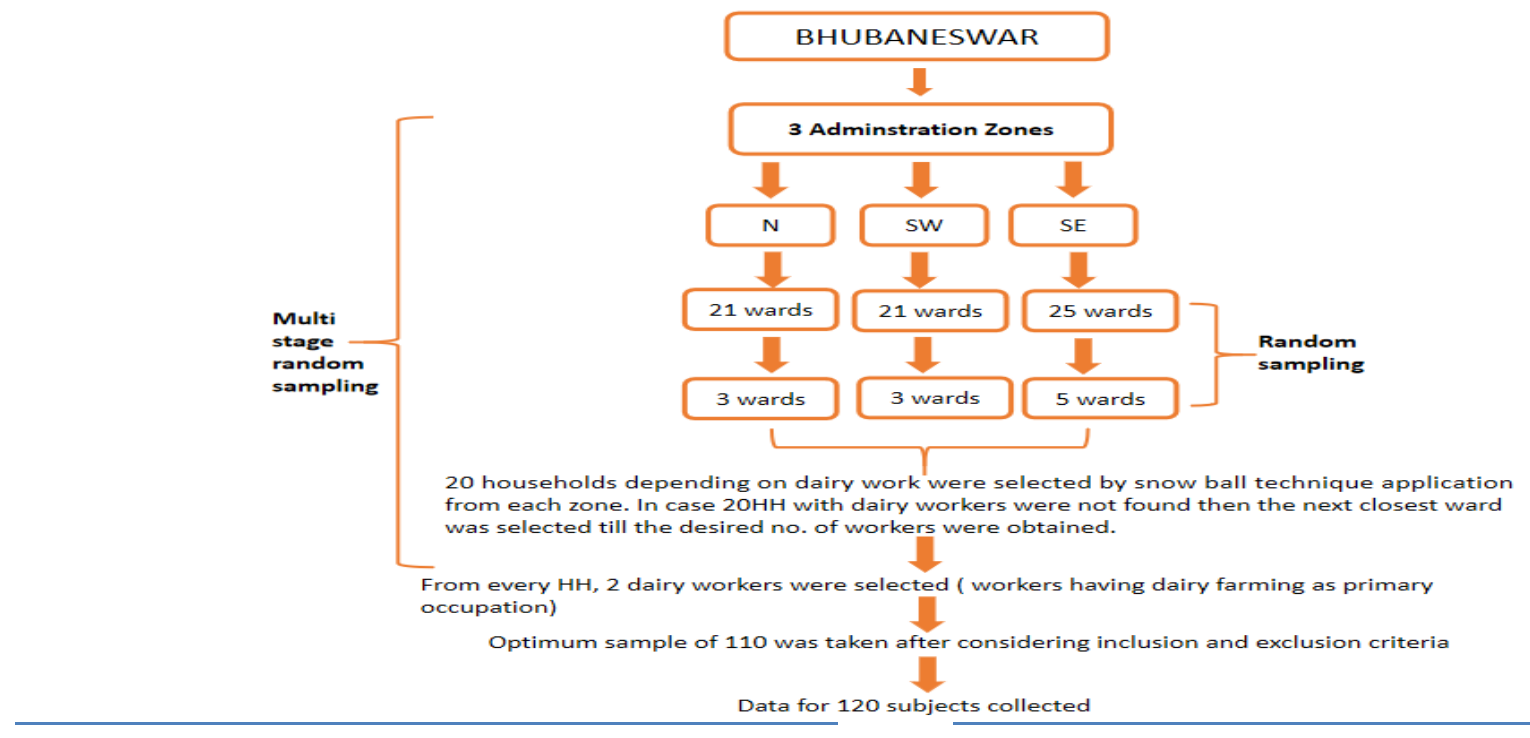

FIGURE 2 DESCRIPTION OF DAIRY HOUSEHOLD

FIGURE 3 DESCRIPTION OF CATTLE SHEDS ( $\mathrm{N}=60)$

$(\mathrm{N}=60)$
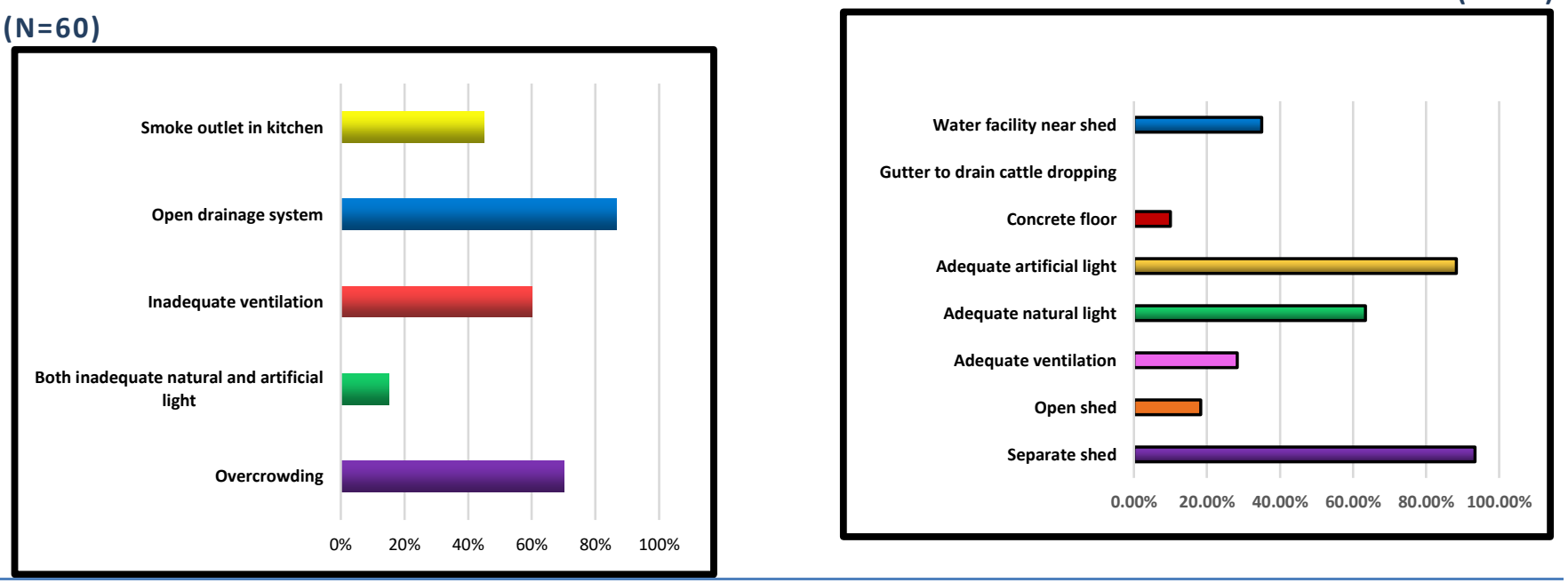

FIGURE 4 AWARENESS VS. PRACTICE AMONG DAIRY WORKERS ON CERTAIN HYGIENE AND DISEASE PREVENTION MEASURES( $\mathrm{N}=120)$
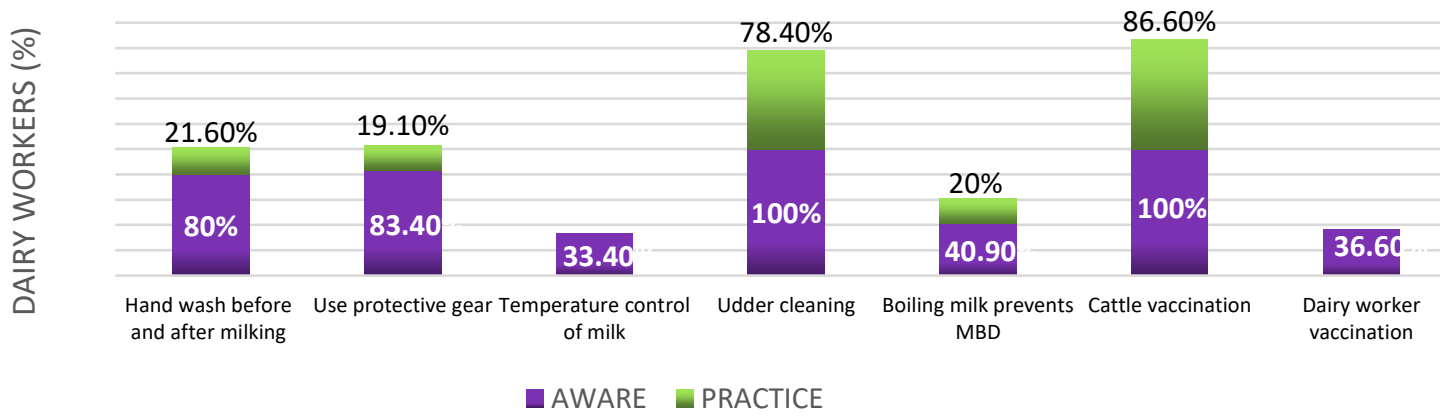